\title{
Radiation Necrosis
}

National Cancer Institute

\section{Source}

National Cancer Institute. Radiation Necrosis. NCI Thesaurus. Code C94479.

T issue necrosis due to radiation exposure. 